https://dx.doi.org/10.4314/ijs.v20i1.20

Ife Journal of Science vol. 20, no. 1 (2018)

\title{
PALYNOLOGICAL STUDY OF RECENT SURFACE SEDIMENTS FROM COASTAL AREA OF LAGOS, NIGERIA
}

\author{
${ }^{+}$Adeleye, M. A., ${ }^{++}$Adebayo, M. B. and ${ }^{+++}$Adeonipekun, P. A. \\ Laboratory of Paleobotany and Palynology, Department of Botany, University of Lagos, Nigeria \\ +matiuadex@gmail.com, madeleye@unilag.edu.ng. ${ }^{++}$adebayomichael4@gmail.com, badebayo@unilag.edu.ng. \\ ${ }^{++}$p1adeonipekun@yahoo.com 2 aadeonipekun@unilag.edu.ng \\ Corresponding author email: adebayomichael4@gmail.com, badebayo@unilag.edu.ng. \\ (Received: $15^{\text {th }}$ November, 2017; Accepted: 3th March, 2018)
}

\section{ABSTRACT}

\begin{abstract}
A palynology study of recent sediments from an $18 \mathrm{~cm}$-core collected from the swamp area in University of Lagos, very close to the Lagos lagoon, was carried out. The recovered palynomorphs included pollen, fern spores, fungal spores and remains, and diatom frustules. Some of the major pollen documented include Arecaceae, Poaceae, Alchornea cordifolia, Amaranthaceae/Chenopodiaceae and Rhizophora. The recovered palynomorph assemblages revealed the recent vegetation changes in this area, which suggests a dominance of open forest vegetation type. Anthropogenic impact especially farming was a key factor that determined palynomorph diversity and abundance.
\end{abstract}

Keywords: Lagos, Palynology, Vegetation changes, Human impact, Palaeoenvironment.

\section{INTRODUCTION}

Palynology has been a veritable tool in palaeoenvironmental reconstruction especially in documenting history and dynamics of past plant communities (Faegri and Iversen, 1975). On a longer time-scale, palynological proxies can identify broad environmental trends both in terrestrial and aquatic settings and the proxies are mostly drawn from sedimentary deposits such as lakes, marine deposits, peatlands and other wetlands such as marshes and swamps (Jeglum and Rydin, 2006; Smol et al., 2001). It is commonly stated that the present condition of the biosphere is the result of the interaction of ecological and historical factors of the past, and the relative significance of each of these factors in shaping present day world can be evaluated (Qian et al., 2007; Emerson and Gillespie, 2008; Alvarez et al., 2009).

This evaluation can be achieved with the use of palynological tools in addition to other independent records of climate and other aspects of the environment such as, physical and chemical aspects. Palynological investigations during the late Quaternary especially the Holocene, have shown that the vegetation of West Africa had undergone considerable changes (Agwu, 1986; Sowunmi, 2004; Njokuocha, 2012). This is believed to be as a result of climate variability coupled with orbital shifts, which have influenced the development and distribution of vegetation over time (Agwu and Beug, 1982; Jahns, 1996).

Conversely, humans have played a major role in perturbing the environment over the last 5,000 years especially in terms of deforestation (State of The World's Forest, 2012). Few palynological studies of Holocene deposits have been carried out in the coastal environments of Lagos, Nigeria (Orijemie, 2014; Orijemie and Sowunmi, 2014). This study aims at contributing to the existing record of the very recent past vegetation changes through the palynology of a sediment core in the coastal area of Lagos. This is to document the recent changes in plant communities in the coastal area of University of Lagos.

Lagos sits on the coastal area of southwestern part of Nigeria between $\sim$ longitudes $2^{\circ} 42^{\prime} \mathrm{E}$ to $3^{\circ} 42^{\prime} \mathrm{E}$ and latitudes $6^{\circ} 22^{\prime} \mathrm{N}$ to $6^{\circ} 42^{\prime} \mathrm{N}$ (Figure 1); and is characterized by a humid tropical climate type. The two major seasons are the wet and dry seasons, which occur from April to November and December to March respectively. Annual rainfall in Lagos ranges between $1381.7 \mathrm{~mm}$ and $2733.4 \mathrm{~mm}$, and monthly records range between $25 \mathrm{~mm}$ and over $400 \mathrm{~mm}$ (Ogundele, 2012). Temperature peak ranges between $29^{\circ} \mathrm{C}$ and $34^{\circ} \mathrm{C}$ while low temperature ranges between $24{ }^{\circ} \mathrm{C}$ and $28{ }^{\circ} \mathrm{C}$ with southwesterly wind and sea breezes prevailing all year round (Ogundele, 2012). University of Lagos is situated in the shoreline of 
Lagos lagoon. A mosaic of swamp forest and open vegetation type characterized by Alchornea cordifolia, Ipomoea carica, Poaceae, Cyperaceae, Acrosticum aureum, Luffa aegyptica, Commelina africana, Terminalia spp., Rhizophora spp, Raphia spp, Albizia sygia, Syzugium guineensis, Mimosa pudica, Anthocleista spp., Drepanocarpus sp., Triumpheta sp. Musa spp. and Mussaenda polita, which presently dominate the area.

\section{MATERIALS AND METHODS}

The study area (Figure 1) is about $50 \mathrm{~m}$ from the brackish lagoon. It falls between longitude $6^{\circ} 31^{\prime} 3.34 " \mathrm{~N}$ and latitude $3^{\circ} 24^{\prime} 4.47^{\prime \prime} \mathrm{E}$. An $18 \mathrm{~cm}$ deep hole was cored and sediments collected at 2 $\mathrm{cm}$ interval, labelled and then subjected to standard palynological treatment, according to Faegri and Iversen (1975). Five grams of each subsample was weighed for palynological preparation and treated with $\mathrm{HCl}, \mathrm{HF}$ and acidified $\mathrm{ZnCl}_{2}$ solutions in order to disintegrate all siliceous and carbonaceous materials. This was followed by acetolysis treatment to remove pollen kit and other cellulosic materials. Two millilitres of glycerine were added to the treated sediment residue for storage and to deduce the volume of the final residue.

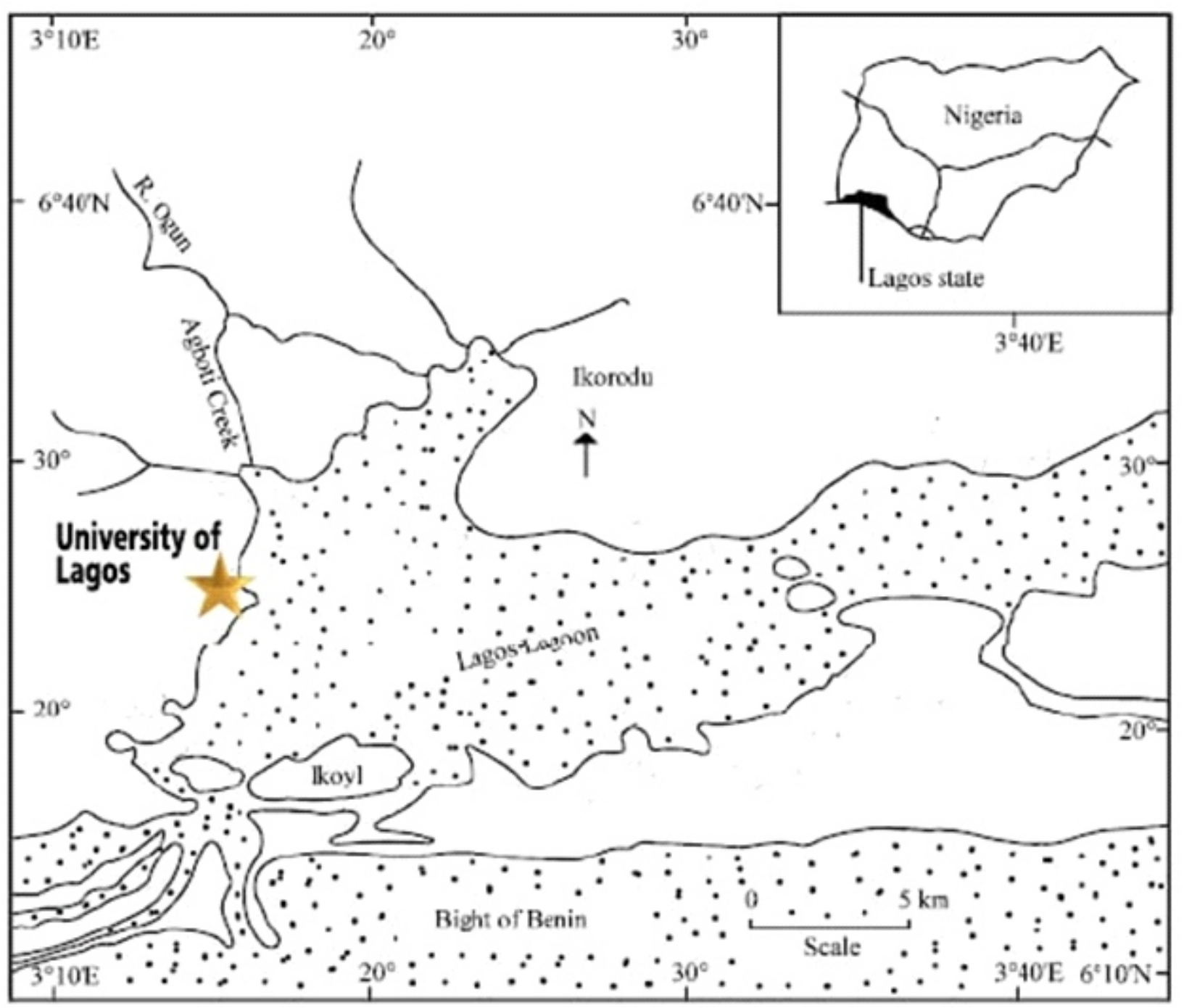

Figure 1: Map of Lagos, showing study site 
Pollen slides ( 2 for each depth) were prepared from the final residue by pipetting $100 \mu$ lof the residue onto the slide. Microscopic analysis was carried out with an Olympus Microscope using $\mathrm{x} 40$ objective lens and identification of palynomorphs was done using published atlases and albums, which include Sowunmi (1995), Traverse (2007) and Gosling et al. (2013), as well as reference materials from the Laboratory of Palaeobotany and Palynology, University of Lagos, Akoka, Lagos Nigeria.

Pollen percentages were calculated using the sum of all pollen grains and fern spores, and pollen diagrams were created using Tilia 2.0.41. Pollen zones were determined by cluster analysis based on similarities in plant assemblages at different depths and pollen taxa were grouped into mangrove savanna, open forest vegetation, fresh water swamp and rain forest. In addition, exaggeration factor of 3 was added to taxa that have very low occurrence for visibility on the pollen diagram.

\section{RESULTS}

A total of nine angiosperm taxa, one aquatic taxon, fern and bryophyte spores, fungal spores and hyphae, as well as dicot cuticle and poorly preserved diatoms were recovered from the sediment core (Table 1, figure 2). Based on cluster analysis, four pollen zones $A-D$ were recognized (Figure 3). In pollen zone A $(18-14 \mathrm{~cm})$ an open mangrove swamp vegetation composed of Poaceae, Cyperaceae, Amaranthaceae, Rhizophora sp., Acrostichum aureum, Nephrolepis undulata, Arecaceae, Rapbia hookerii, Pteridophyte spores, Malvaceae, A. cordifolia, Malus communis and Elaeis guineensis prevailed (Table 1). Representative taxa of pollen zone B $(14-8 \mathrm{~cm})$ include Poaceae, Amaranthaceae, Rhizophora sp., Nephrolepis undulata, Nymphaea lotus, Arecaceae, Pteridophyte spores, degraded diatoms, $A$. cordifolia and a few Bryophyte spores, which represent an open mangrove vegetation setting. Taxa assemblage recovered from pollen zone $\mathrm{C}(8-4 \mathrm{~cm})$ include Asteraceae, A. cordifolia, Typha sp., Poaceae, Cyperaceae, Arecaceae, Terminalia sp., Allophylus africanus, Elaeis guineensis, Monolete, Trilete and Pteridophyte spores, which represent a mix of mangrove, rainforest and open forest vegetation. From the topmost zone: zone D $(4-0 \mathrm{~cm})$, the taxa recovered are mix of fresh water, mangrove, rainforest and open vegetation types; they included Poaceae, Cyperaceae, Rhizophora sp., Nephrolepis undulata, Arecaceae, Pteridophyte spore, Berlinia grandiflora, Elaeis guineensis, Terminalia sp. and $A$. cordifolia.

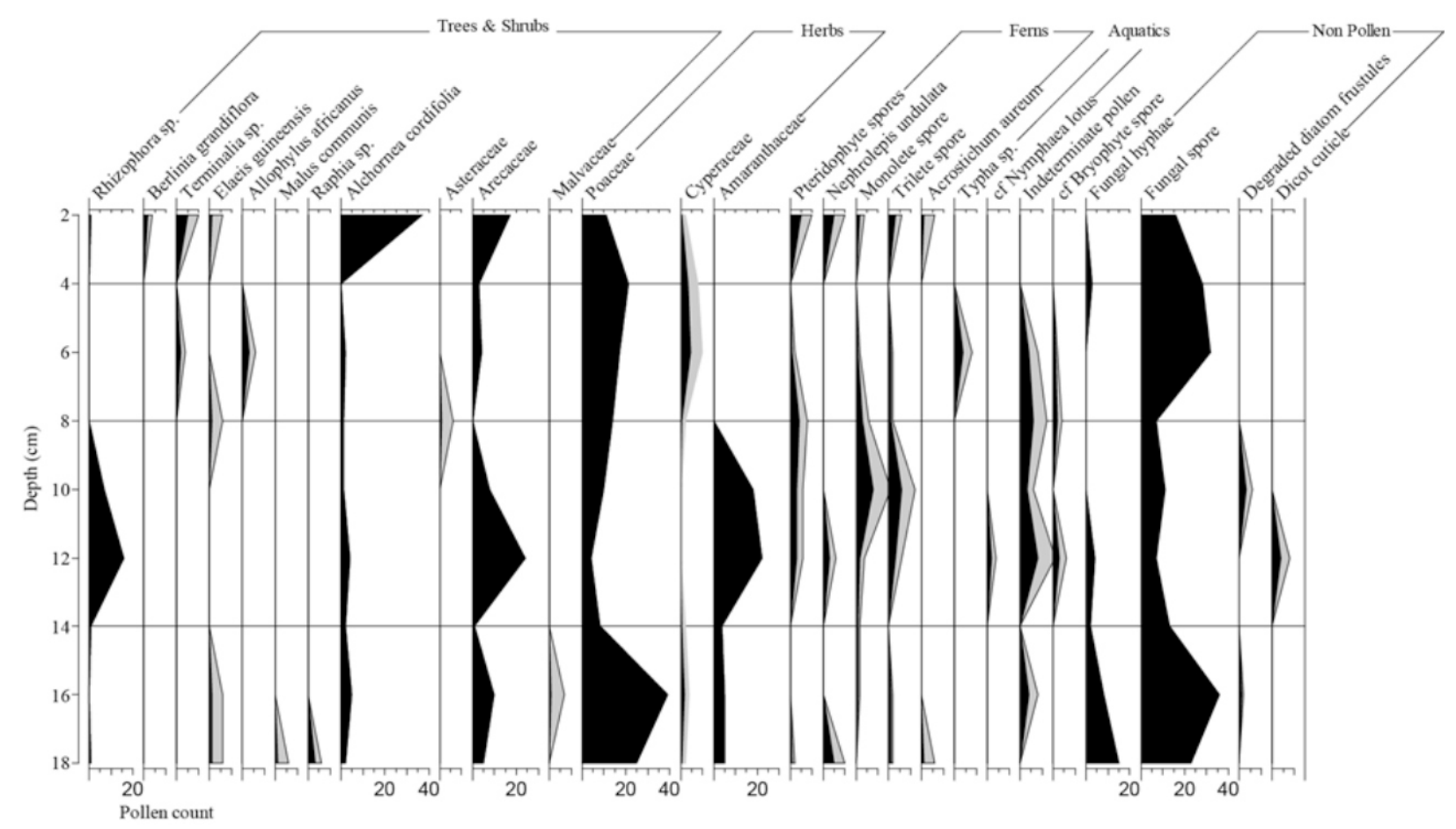

Figure 2: Diagram showing all recovered pollen and non-pollen palynomorphs 
Table 1: Distribution of recovered Palynomorphs of studied shallow core

\begin{tabular}{|l|l|l|l|l|l|l|l|l|l|}
\hline Palynomorphs/Depth (cm) & $\mathbf{2}$ & $\mathbf{4}$ & $\mathbf{6}$ & $\mathbf{8}$ & $\mathbf{1 0}$ & $\mathbf{1 2}$ & $\mathbf{1 4}$ & $\mathbf{1 6}$ & $\mathbf{1 8}$ \\
\hline Poaceae & 11 & 21 & 17 & 14 & 10 & 4 & 8 & 39 & 25 \\
\hline Cyperaceae & 1 & 4 & 5 & 1 & 0 & 0 & 1 & 2 & 1 \\
\hline Amaranthaceae & 0 & 0 & 0 & 0 & 18 & 22 & 4 & 5 & 5 \\
\hline Rhizophora sp. & 1 & 0 & 0 & 0 & 7 & 16 & 1 & 0 & 1 \\
\hline Acrostichum aureum & 1 & 0 & 0 & 0 & 0 & 0 & 0 & 0 & 1 \\
\hline Typha sp. & 0 & 0 & 4 & 0 & 0 & 0 & 0 & 0 & 0 \\
\hline Nephrolepis undulata & 5 & 0 & 0 & 0 & 0 & 3 & 0 & 0 & 5 \\
\hline cf Nympheae lotus & 0 & 0 & 0 & 0 & 0 & 2 & 0 & 0 & 0 \\
\hline Arecaceae & 17 & 3 & 4 & 0 & 8 & 24 & 1 & 10 & 5 \\
\hline Degraded diatom frustules & 0 & 0 & 0 & 0 & 3 & 0 & 0 & 1 & 0 \\
\hline Raphia hookerii & 0 & 0 & 0 & 0 & 0 & 0 & 0 & 0 & 3 \\
\hline Monolete spore & 2 & 0 & 1 & 3 & 8 & 2 & 1 & 1 & 0 \\
\hline Trilete spore & 3 & 0 & 1 & 1 & 6 & 3 & 0 & 1 & 1 \\
\hline Pteridophyte spores & 5 & 0 & 1 & 4 & 3 & 3 & 0 & 0 & 1 \\
\hline Malvaceae & 0 & 0 & 0 & 0 & 0 & 0 & 0 & 1 & 0 \\
\hline Alchornea cordifolia & 37 & 0 & 2 & 1 & 1 & 4 & 2 & 5 & 2 \\
\hline Asteraceae & 0 & 0 & 0 & 1 & 0 & 0 & 0 & 0 & 0 \\
\hline Malus communis & 0 & 0 & 0 & 0 & 0 & 0 & 0 & 0 & 1 \\
\hline Allophylus africanus & 0 & 0 & 3 & 0 & 0 & 0 & 0 & 0 & 0 \\
\hline Terminalia sp. & 5 & 0 & 2 & 0 & 0 & 0 & 0 & 0 & 0 \\
\hline Berlinia glandifolia & 2 & 0 & 0 & 0 & 0 & 0 & 0 & 0 & 0 \\
\hline Elaeis guineensis & 1 & 0 & 0 & 1 & 0 & 0 & 0 & 1 & 1 \\
\hline Indeterminate pollen & 0 & 0 & 4 & 6 & 3 & 8 & 0 & 4 & 0 \\
\hline Fungal spore & 16 & 28 & 32 & 7 & 11 & 7 & 13 & 36 & 23 \\
\hline Fungal hyphae & 0 & 3 & 0 & 0 & 0 & 4 & 2 & 8 & 15 \\
\hline Dicot cuticle & 0 & 0 & 0 & 0 & 0 & 4 & 0 & 0 & 0 \\
\hline cf Bryophyte spore & 0 & 0 & 1 & 2 & 0 & 3 & 0 & 0 & 0 \\
\hline TOTAL & $\mathbf{1 0 7}$ & $\mathbf{5 9}$ & $\mathbf{7 7}$ & $\mathbf{4 1}$ & $\mathbf{7 8}$ & $\mathbf{1 0 9}$ & $\mathbf{3 3}$ & $\mathbf{1 1 4}$ & $\mathbf{9 0}$ \\
\hline & & & & & & & & \\
\hline
\end{tabular}

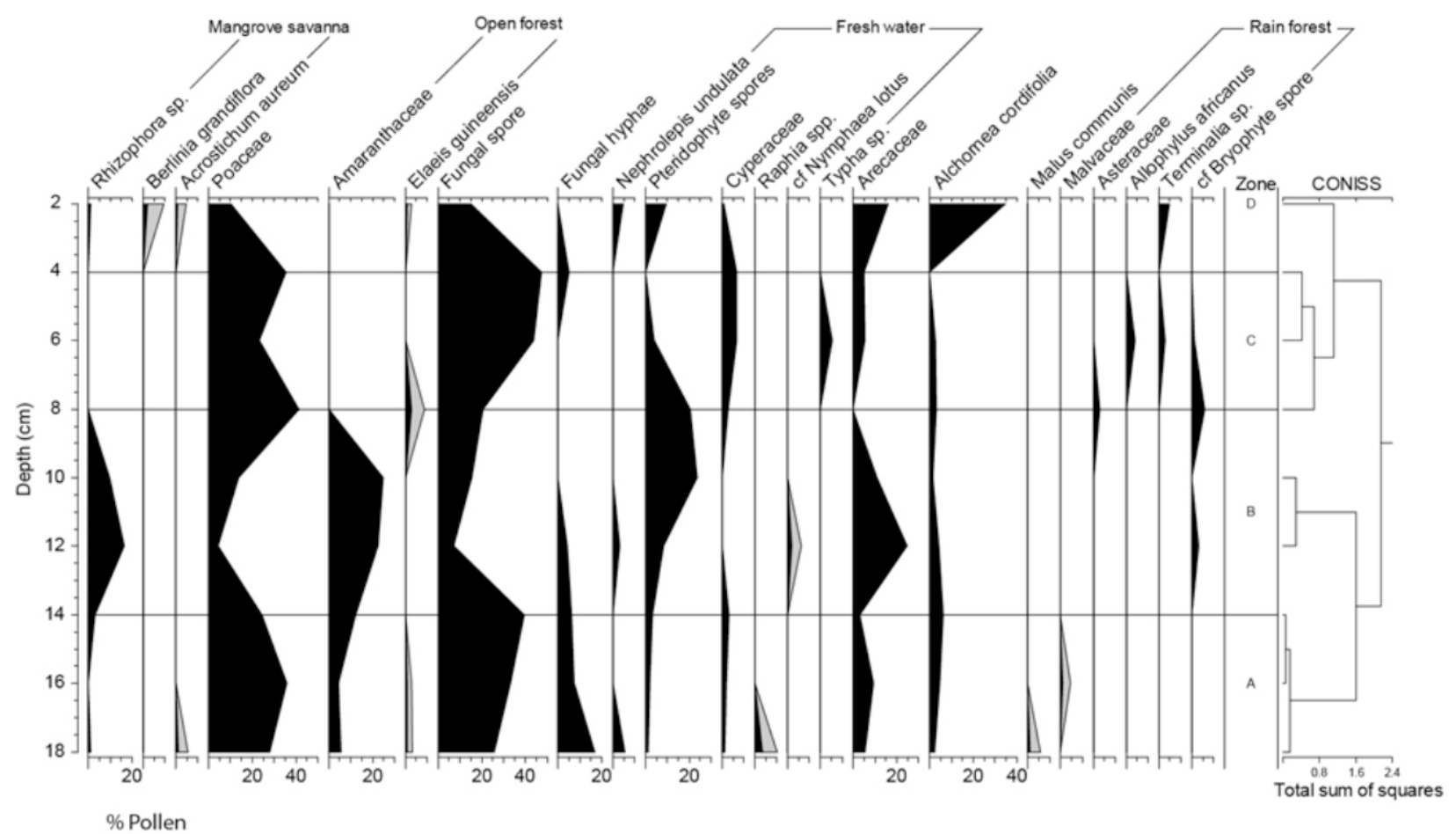

Figure 3: Pollen diagram showing taxa groups with zones based on cluster analysis 
Table 2: Percentage sum of pollen and spores

\begin{tabular}{|l|r|r|r|r|r|r|r|r|r|}
\hline Palynomorph/Depth (cm) & $\mathbf{2}$ & $\mathbf{4}$ & $\mathbf{6}$ & $\mathbf{8}$ & $\mathbf{1 0}$ & $\mathbf{1 2}$ & $\mathbf{1 4}$ & $\mathbf{1 6}$ & $\mathbf{1 8}$ \\
\hline Poaceae & 10.3 & 35.6 & 23.3 & 41.2 & 13.9 & 4.1 & 24.2 & 35.8 & 28.1 \\
\hline Cyperaceae & 0.9 & 6.8 & 6.8 & 2.9 & 0.0 & 0.0 & 3.0 & 1.8 & 1.1 \\
\hline Amaranthaceae & 0.0 & 0.0 & 0.0 & 0.0 & 25.0 & 22.7 & 12.1 & 4.6 & 5.6 \\
\hline Rhizophora spp. & 0.9 & 0.0 & 0.0 & 0.0 & 9.7 & 16.5 & 3.0 & 0.0 & 1.1 \\
\hline Acrostichum aureum & 0.9 & 0.0 & 0.0 & 0.0 & 0.0 & 0.0 & 0.0 & 0.0 & 1.1 \\
\hline Typha sp. & 0.0 & 0.0 & 5.5 & 0.0 & 0.0 & 0.0 & 0.0 & 0.0 & 0.0 \\
\hline Nephrolepis undulata & 4.7 & 0.0 & 0.0 & 0.0 & 0.0 & 3.1 & 0.0 & 0.0 & 5.6 \\
\hline cf Nymphaea lotus & 0.0 & 0.0 & 0.0 & 0.0 & 0.0 & 2.1 & 0.0 & 0.0 & 0.0 \\
\hline Arecaceae & 15.9 & 5.1 & 5.5 & 0.0 & 11.1 & 24.7 & 3.0 & 9.2 & 5.6 \\
\hline Raphia spp. & 0.0 & 0.0 & 0.0 & 0.0 & 0.0 & 0.0 & 0.0 & 0.0 & 3.4 \\
\hline Pteridophyte spores & 9.3 & 0.0 & 4.1 & 20.6 & 23.6 & 8.2 & 3.0 & 1.8 & 1.1 \\
\hline Malvaceae & 0.0 & 0.0 & 0.0 & 0.0 & 0.0 & 0.0 & 0.0 & 0.9 & 0.0 \\
\hline Alchornea cordifolia & 34.6 & 0.0 & 2.7 & 2.9 & 1.4 & 4.1 & 6.1 & 4.6 & 2.2 \\
\hline Asteraceae & 0.0 & 0.0 & 0.0 & 2.9 & 0.0 & 0.0 & 0.0 & 0.0 & 0.0 \\
\hline Malus communis & 0.0 & 0.0 & 0.0 & 0.0 & 0.0 & 0.0 & 0.0 & 0.0 & 1.1 \\
\hline Allophylus africanus & 0.0 & 0.0 & 4.1 & 0.0 & 0.0 & 0.0 & 0.0 & 0.0 & 0.0 \\
\hline Terminalia sp. & 4.7 & 0.0 & 2.7 & 0.0 & 0.0 & 0.0 & 0.0 & 0.0 & 0.0 \\
\hline Berlinia grandiflora & 1.9 & 0.0 & 0.0 & 0.0 & 0.0 & 0.0 & 0.0 & 0.0 & 0.0 \\
\hline Elaeis guineensis & 0.9 & 0.0 & 0.0 & 2.9 & 0.0 & 0.0 & 0.0 & 0.9 & 1.1 \\
\hline Fungal spore & 15.0 & 47.5 & 43.8 & 20.6 & 15.3 & 7.2 & 39.4 & 33.0 & 25.8 \\
\hline Fungal hyphae & 0.0 & 5.1 & 0.0 & 0.0 & 0.0 & 4.1 & 6.1 & 7.3 & 16.9 \\
\hline cf Bryophyte spore & 0.0 & 0.0 & 1.4 & 5.9 & 0.0 & 3.1 & 0.0 & 0.0 & 0.0 \\
\hline
\end{tabular}

Table 3: Sum of pollen and spores

\begin{tabular}{|l|r|r|r|r|r|r|r|r|r|}
\hline Palynomorph/Depth (cm) & $\mathbf{2}$ & $\mathbf{4}$ & $\mathbf{6}$ & $\mathbf{8}$ & $\mathbf{1 0}$ & $\mathbf{1 2}$ & $\mathbf{1 4}$ & $\mathbf{1 6}$ & $\mathbf{1 8}$ \\
\hline Elaeis guineensis & 1 & 0 & 0 & 1 & 0 & 0 & 0 & 1 & 1 \\
\hline Berlinia glandifolia & 2 & 0 & 0 & 0 & 0 & 0 & 0 & 0 & 0 \\
\hline Raphia hookeri & 0 & 0 & 0 & 0 & 0 & 0 & 0 & 0 & 3 \\
\hline Rhizophora & 1 & 0 & 0 & 0 & 7 & 16 & 0 & 0 & 1 \\
\hline Arecaceae & 17 & 3 & 4 & 0 & 8 & 24 & 1 & 10 & 5 \\
\hline Alchornea cordifolia & 37 & 0 & 2 & 1 & 1 & 4 & 2 & 5 & 2 \\
\hline Amaranthaceae & 0 & 0 & 0 & 0 & 18 & 22 & 4 & 5 & 5 \\
\hline Poaceae & 11 & 21 & 17 & 14 & 10 & 4 & 8 & 39 & 25 \\
\hline Cyperaceae & 1 & 4 & 5 & 1 & 0 & 0 & 1 & 2 & 1 \\
\hline Acrostichum aureus & 1 & 0 & 0 & 0 & 0 & 0 & 0 & 0 & 1 \\
\hline Trilete spore & 3 & 0 & 1 & 1 & 6 & 3 & 0 & 1 & 1 \\
\hline Nephrolepis undulata & 5 & 0 & 0 & 0 & 0 & 3 & 0 & 0 & 5 \\
\hline Pteridophyte spore & 5 & 0 & 1 & 4 & 3 & 3 & 0 & 0 & 1 \\
\hline cf Bryophyte Spore & 0 & 0 & 1 & 2 & 0 & 3 & 0 & 0 & 0 \\
\hline cf Nympheae lotus & 0 & 0 & 0 & 0 & 0 & 2 & 0 & 0 & 0 \\
\hline Sum & 84 & 28 & 31 & 24 & 53 & 84 & 16 & 63 & 51 \\
\hline
\end{tabular}

\section{DISCUSSION AND CONCLUSION}

In pollen zone $A(18-14 \mathrm{~cm})$, the predominance of Poaceae pollen with an average count of 72 pollen, in addition to low recovery of Pteridophyte spores and sparse distribution of Elaeis guineensis pollen suggests an open vegetation in this interval (Table 1). pollen zone B $(14-8 \mathrm{~cm})$ recorded the dominance of Amaranthaceae, Rhirophora and Arecaceae pollen with few degraded diatom remains. The low proportions of Poaceae and $A$. cordifolia, and the overall floristic composition may suggest a mangrove vegetation type. In addition, the significant recovery of Amaranthaceae in this zone indicates human farming activities or possibly inundation consequence by marine transgression. The brackish water incursion might have promoted the presence of salt loving Amaranthaceae such as, Salicornia (Slenzka et al., 2013).

Abundant recovery of Poaceae and Cyperaceae pollen characterized the interval represented by 
pollen zone $\mathrm{C}(8-4 \mathrm{~cm})$. However, the occurrence of Allophylus africanus, Terminalia sp., and fern spores, although in low proportions, with low recovery of Arecaceae, A. cordifolia, Nephrolepis undulata and Nympheae lotus may indicate a marshy or swampy open grassland vegetation. This vegetation setting is similar to the current vegetation in some adjacent areas to the study site. Following this zone is pollen zone $\mathrm{D}(4.0-0.0 \mathrm{~cm})$. The pollen assemblage of this zone include Terminalia sp., Berlinia, Elaeis guineensis, A. cordifolia and Arecaceae. Fern spores particularly Acrostichum aureum were recovered in abundance along with fungal spores. A. cordifolia, Arecaceae and Poaceae dominated this interval although, Poaceae count decreased to an average of 16 , and these taxa form majority of the plants growing in the study area presently (Figure 1).

The close proximity of the study area to the lagoon may have had tremendous impact on the overall vegetation changes, and the study area is mostly wet all year round due to increase in lagoon tide during raining season. This tide also reduces in the dry season, leaving the study area in a marshy/swampy state, and sometimes fairly dry in extreme prolonged dry seasons. Overall, an open swampy vegetation type prevailed in the entire core, which is similar to the surface portion of other Holocene studies that have been carried out in Nigeria in terms of presence of open and swampy vegetation taxa (Sowunmi, 1981; Wang et al., 2008). Anthropogenic activities such as farming, deforestation, construction, burning, and increasing human population are factors, which could possibly have contributed to the open nature of the vegetation. Increased human populations in coastal areas usually result in increased demand for space to erect residential and office buildings, tourist resorts, and recreation areas (Martínez et al., 2004).

\section{REFERENCES}

Agwu, C.O.C. 1986. History of climate and vegetation of east central Nigeria as deduced from pollen analysis: Preliminary investigation. Bulletin De Liaison 76: 5-7.

Agwu, C.O.C. and Beug, H.J. 1982. Palynological studies of marine sediment of West African coast. Meteor Forschungsergebnisse Reibe 36:1-30.
Alvarez, N., Thiel-Egenter, C., Tribsch, A., Holderegger,sR., Manuel, S., Schonswetter, P., Taberlet, P., Brodbeck, S., Gaudeul, M., Gielly, L., Kupfer, P., Mason, G., Negrini, R., Paun, O., Pellecchia, M., Riousx, D., Schupfer, F., van Loo, M., Winkler, M. and Gugerli, F. 2009. History or ecology: substrate type as a major driver of spatial genetic structure in alpine plants. Ecology Letters 12(7): 632-640.

Emerson, B.C. and Gillespie, R.G. 2008. Phylogenetic analysis of community assembly and structure over space and time. Trends in Ecology and Evolution 23(11): 619-630.

Faegri, K. and Iversen, J. 1975. Textbook of pollen analysis. Hafner Press, New York, 295 pp.

Faegri, K. and Iversen, J. 1975. Textbook of pollen analysis, (eds) Faegri K. Munksgaard, Copenhagen, 295 pp.

Gosling, W. D., Miller, C. S. and Livingstone, D. A. 2013. Atlas of the tropical West African pollen flora. Review of Palaeobotany and Palynology 199: 1-135.

Jahns, S. 1996. Vegetation history and climate changes in West Equatorial Africa during the Pleistocene and Holocene based on a marine pollen diagram from the Congo fan. Vegetation History and Archaebotany 5: 505-616.

Jeglum, J. and Rydin, H. 2006. The Biology of Peatlands. Oxford University Press Incorporated, New York. 343pp.

Martínez, J., Chuvieco, E., and Martin, M.P. 2004. Estimating human risk factors in wildland fires in Spain using logistic regression: II. International Symposium on Fire Economics, Planning and Policy: A Global Vision. University of Cordoba, CD-Rom, Córdoba, p. 15.

Njokuocha, R.C. 2012. Holocene pollen deposits and recent vegetation distribution of Obayi Lake, Nsukka. Quaternary International262:20-24

Ogundele, F. O. 2012. Variation in the PhysicoChemical Properties of Badagry and Ikorodu Soils, Lagos Nigeria. International Journal of Humanities and Social Science, 2 (8): 244-258.

Orijemie, E.A. 2014. A palynological and 
archaeological investigation of the environment and human occupation of the rainforest of southwestern Nigeria during the late Holocene period Azania: Archaeological Research in Africa 49 (2): p283.

Orijemie, E. A. and Sowunmi, M. A. 2014. Humans and the Mangrove in Southern Nigeria. In: (eds.) Stevens, C. J., Nixon, S. Anne-Murray, M. and Fuller, D. Q. The Archaeology of African Plant. Pp 103-112.

Qian, H., White, P.S. and Song, J.S. 2007. Effects of regional versus ecological factors on plant species richness: An intercontinental analysis. Ecology 88(6): 1440-1453.

Slenzka, A., Mucina, L. and Kadereit, G. 2013. Salicornia L. (Amaranthaceae) in South Africa and Namibia: rapid spread and ecological diversification of cryptic species, Botanical Journal of the Linnean Society, 172: 175-186.

Smol, J. P., Birks, H. J. B. and Last, W. M. (eds.). 2001. Tracking Environmental Changes Using Lake Sediments. Terrestrial, Algal and Siliceous Indicators, Kluwer Academic Publisher, Dordrecht, The Netherlands 3: $371 \mathrm{pp}$.
Sowumi, M.A. 2004. Aspects of Nigeria coastal vegetation in the Holocene: Some recent insights. In: Past Climate Variability Through Europe and Africa, (eds), R.W. Battarbee, F. Gasse and C.E. Stickley. Kluwer Academic Publishers, Dordrecht, 199-218pp.

Sowunmi, M. A. 1981. Aspects of Late Quaternary Vegetational Changes in West Africa. Journal of Biogeography 8, 457-474.

Sowunmi, M. A. 1995. Pollen of Nigerian plants. Grana 34:120-141.

State of the World's Forest. 2012. Food and Agriculture Organization of the United Nations, 46pp

Traverse, A. 2007. Paleopalynology. Springer 28 (2): 816pp.

Wang, H., Holmes, J. A., Street-Perrott, F. A., Waller, M. P. and Perrott, R. A. 2008. Holocene environmental change in the West African Sahel: sedimentological and mineral-magnetic analyses of lake sediments from Jikariya Lake, northeastern Nigeria. Journal of Quaternary Science 23: 449-460. 